\title{
THE NEW METHOD OF PROCESSING OF CAROTENE- CONTAINING VEGETABLES FOR THE PRODUCTION OF NANOPRODUCTS USING COMBI-STEAMERS AND FINE-DISPERSED COMMINUTION
}

\author{
Raisa Pavlyuk \\ Department of Technology Processing of Fruits, Vegetables and Milk \\ Kharkov State University of Food Technology and Trade \\ 333 Klochkivska str., Kharkov, Ukraine, 61051 \\ ktppom@ukr.net \\ Viktoriya Pogarska \\ Department of Technology Processing of Fruits, Vegetables and Milk \\ Kharkov State University of Food Technology and Trade \\ 333 Klochkivska str., Kharkov, Ukraine, 61051 \\ viktoria.pogarskaya@ukr.net \\ Ludmila Radchenko \\ Kharkov Trade-Economic Colledge of \\ Kyiv National University of Trade and Economics \\ 202 Klochkivskaya str., Kharkiv, Ukraine, 61045 \\ kharkiv@htek.com.ua \\ David Tauber Roman \\ Academy of Hospitality and Catering in Poznan \\ 19 Nieszawska str., Poznan, Poland, 61-022 \\ wshigua@i.ua \\ Nadiya Timofeyeva \\ Department of Technology Processing of Fruits, Vegetables and Milk \\ Kharkov State University of Food Technology and Trade \\ 333 Klochkivska str., Kharkov, Ukraine, 61051 \\ kdp2010@yandex.ua

\section{Tatyana Kotuyk} \\ Department of Technology Processing of Fruits, Vegetables and Milk \\ Kharkov State University of Food Technology and Trade \\ 333 Klochkivska str., Kharkov, Ukraine, 61051 \\ kotyuk.tatyana@mail.ru
}

Abstract

The aim of the work is elaboration of the principally new method of deep processing of carotene-containing vegetables $(\mathrm{CCV})$. For attaining this aim was used the complex effect of steam-thermal processing and fine-dispersed comminution for preservation and extraction of biologically active substances from the raw material and getting products of nanosized form. There was also used the new generation of equipment: combi-steamer and dine-dispersed comminutor.

There was elaborated the new method of deep processing, alternative to cryogenic one. This method is based on the complex effect of steam-thermal processing and fine-disperse comminution using the modern equipment (combi-steamer and fine-dispersed comminutor) that is used at enterprises of restaurant business. This method allows use biological potential of the raw material more fully ( $2 \ldots 3$ times more) and get the foodstuff in nanoform.

It was shown, that at steam-thermal processing of vegetables (carrot, pumpkin) in combi-steam antioxidant enzymatic processes flow with less intensity ( $3 . . .4$ times less) than at blanching.

It was established, that at the steam-thermal processing in combi-steamer in 10 minutes in carotene-containing vegetables takes place not only conservation of $\beta$-carotene but also increase of its mass fraction in 2..2,5 times (comparing with initial raw material). Mechanism of this process is connected with fact that carotenoids are transformed from the hidden state (frms associated with biopolymers) into free form that is fixed by chemical methods. 
It was also established, that after steam-thermal processing and fine-dispersed comminution of carotene-containing vegetables at preparation of puree takes place the significant increase of extraction of ascorbic acid and $\beta$-carotene comparing with initial raw material that is for pumpkin 2 and 3 times more and for carrot 1,7 and 2,5 times more, respectively.

It was established, that complex use of the new equipment at steam-thermal processing of vegetable raw material in combi-steamer with fine-dispersed comminution gives a possibility to get puree, which quality is approximated to the one of puree, received using cryogenic processing of product (especially, by the content of $\beta$-carotene and other biologically active substances (BAS).

Keywords: carotene-containing vegetables, steam-thermal processing, fine-dispersed comminution, products in nanoform.

\section{Introduction}

The aim of the work is elaboration of the principally new method of deep processing of carotene-containing vegetables $(\mathrm{CCV})$. For attaining this aim was used the complex effect of steam-thermal processing and fine-dispersed comminution for preservation and extraction of biologically active substances from the raw material and getting products of nanosized form.The was also used the new generation of equipment: combi-steamer and dine-dispersed comminutor.

Kharkov state university of food technology and trade (KSUFTT, Kharkov, Ukraine) together with Kharkov Trade-Economic Colledge of Kyiv National University of Trade and Economics, Municipal enterprise "Combine of child food" (Kharkov, Ukraine) and Academy of hospitality and catering in Poznan city (Poland) elaborated principally new method of the deep processing of vegetable raw material without using cold. The new method, alternative to cryogenic processing, allows not only maximally preserve, but also more fully use biological potential of vegetable raw material and transform BAS and polymers from the associated state in nanoform. This method is based on the process of non-enzymatic catalysis-mechanolysis (destruction of nanocomplexes that contain biologically active substances in hidden form) in steam-thermally processed vegetable raw material that leads to getting product in nanosized form.

As innovation in the work it was offered to use the complex effect on carotene-containing vegetables at steam-thermal processing and fine-dispersed comminution using the new generation of highly effective modern equipment - combi-steamer and activator - homogenizer-comminutor [1-4].

\section{Materials and methods of research}

\section{1. Studied materials and equipment used in experiments}

The study was carried out at the department of technology processing of fruits, vegetables and milk of KSUFTT (Kharkov, Ukraine) in laboratory of "Innovative cryo- and nanotechnologies of vegetable additives and wellness products". The steam-thermal processing was carried out in combi-steamer UNOX SPA of XVC series (Italy) that has 70 programs that differ by temperature regimes, intensity of steam supply, circulation or blowing by air (Fig. 1).

As objects of research there was used carotene-containing raw material - carrot (Fig. 2) and pumpkin (Fig. 3) and fine-dispersed puree of carrot and pumpkin in nanosized form (Fig. 4).

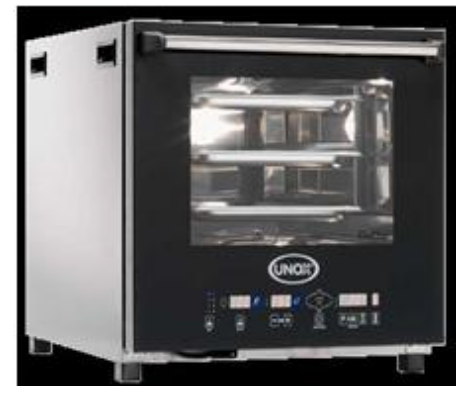

Fig. 1. Combi-steamer UNOX SPA of XVC series (Italy) 


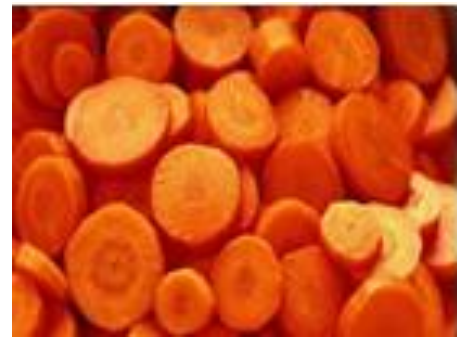

Fig. 2. Initial raw material (carrot)

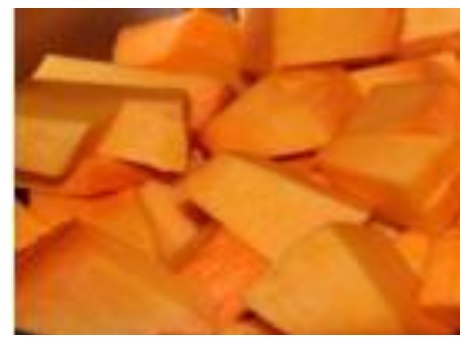

Fig. 3. Initial raw material (pumpkin)

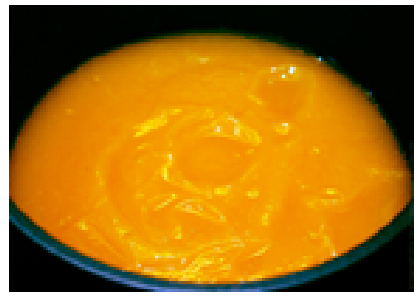

Fig. 4. Nanoproduct of carrot after steam-thermal processing and fine-dispersed comminution

At elaboration of principally new method of vegetables processing there was carried out comparison of effect of the different types of steam-thermal processing in combi-steamer and blanching on traditional equipment (blancher) on carotene-containing raw material (carrot and pumpkin) on the basic enzymatic, biochemical and mechanochemical processes. The steam-thermal processing of $\mathrm{CCV}$ samples (carrot, pumpkin) was carried out at such regimes: temperature in combi-steamer $-105^{\circ} \mathrm{C}$, in product $-70 \ldots 75^{\circ} \mathrm{C}$, regime of steam creation $-100 \%$ (that corresponds to the maximal amount of steam). In parallel there was carried out the thermal processing of raw material by blanching on traditional equipment (blancher - double boiler Kaiserhoff KH-8000, Germany). Blanching was carried out by immersion in boiling water at $\mathrm{t}=100{ }^{\circ} \mathrm{C}$ during $10 \mathrm{~min}$, $20 \mathrm{~min}$ and $30 \mathrm{~min}$. The steam-thermal processing was carried out during 30 minutes with samples collection each 5 minutes. The fine-dispersed comminution was carried out in activator - homogenizer-comminutor.

\section{2. Methodologies of determination of parameters of studied samples}

The comparison of quality of initial vegetable raw material and products of it was carried out by enzymatic activity of oxidant enzymes (peroxidase, polyphenol oxidase), content of $\beta$-carotene mass fraction, low molecular phenol compounds and L-ascorbic acid. The content of aforesaid substances is the one of assessment criteria of the raw material quality, accepted in international practice $[1,2,5,6]$. For assessment of samples quality there were used standard methods (especially, the methods of determination of mass fraction of $\beta$-carotene, L-ascorbic acid, phenol compounds, flavonol glycoside) excluding the method of enzymatic activity determination. The methods of determination of aforesaid substances are given below. 
Determination of carotene-content (especially $\beta$-carotene) was controlled by colorimetric Muri method after exclusion of carotene from product by organic solvent and purification of carotene from concomitant color substances using column chromatograpy.

Determination of L-ascorbic acid was carried out by the method of visual and potentiometric titration by solution of 2,6-Na dichloroindorphenol.

Determination of the general quality of low molecular phenol compounds was carried out by colorimetric method of Folin-Denis.

Determination of the sum of flavonol glycosides was carried out by colorimetric method, based on the flavonols property to change the absorption spectrum at presence of aluminum salts and at $\mathrm{pH}$ change. Maximal flavonol absorption is within $350 \ldots 390 \mathrm{~nm}$. In alkaline medium or at presence of aluminum salts the light absorption displaces by $20 \mathrm{~nm}$ and more to the longer waves. This ability is used at determination of flavonol glycosides by Muri method by reaction of $2 \%$ $\mathrm{AlCl}_{3}$. The calculation of flavonol glycosides was carried out by rutin.

Determination of enzymatic activity (peroxidase and polyphenol oxidase) was carried out by the conventional method of M. Mikhlin and Z. S. Bronovitska, based on the quinone ability to oxidize ascorbic acid.

\section{Results of research}

It was established, that at the steam-thermal processing of carotene-containing vegetables in combi-steamer (at aforesaid regimes) in 10 minutes takes place not only conservation of $\beta$-carotene but also increase of its mass fraction in 2...2,5 times comparing with initial raw material. It takes place at the expense of carotene release from the hidden state (forms associated with biopolymers) into free form that is fixed by chemical methods of research. The same regularities are established also at blanching. It is also established, that the losses of vitamin $\mathrm{C}$ at thermal processing of carotene-containing vegetables in combi-steamer are 2 times less that at blanching. Thus, after 20 minutes of thermal processing in combi-steamer the mass fraction of L-ascorbic acid was preserved in $65 . .80 \%$, whereas after blanching - in $40 . .50 \%$.

It was also revealed, that after steam-thermal processing and fine-dispersed comminution of carotene-containing vegetables at preparation of puree takes place the significant increase of $\mathrm{L}$-ascorbic acid and $\beta$-carotene extraction that is comparing with the raw material: for pumpkin -2 and 3 times more, for carrot - 1,7 and 2,5 times more. It was elucidated the mechanism of this process, connected with mechanical destruction and mechanical cracking (destruction) of nanocomplexes of biopolymer-carotenoid, biopolymer ascorbic acid. At the same time there takes place the release of hidden associated forms of carotene and L-ascorbic acid of nanoassciates and nanocomplexes with proteins, polysaccharides, tanning substances and other in free form. These substances are controlled by the chemical methods of research $[7,8]$.

It was established, that complex use of the new equipment at steam-thermal processing of vegetable raw material in combi-steamer with fine-dispersed comminution gives a possibility to get puree, which quality is approximated to the one of puree, received using cryogenic processing of product, by the biologically active substances (BAS) content (Table 1).

Thus, for example, the mass fraction of $\beta$-carotene in $100 \mathrm{~g}$ of fresh pumpkin is $8,5 \mathrm{mg}$, in fine-dispersed puree $-26,5 \mathrm{mg}$ in cyopuree $-32,2 \mathrm{mg}$. Mass fraction of $\beta$-carotene in $100 \mathrm{~g}$ of fresh carrot and fine-disperse puree of it is $9,2 \mathrm{mg}$ and $24,6 \mathrm{mg}$, respectively, in cryopuree $-28,8 \mathrm{mg}$ in $100 \mathrm{~g}$.

Thus, it was established, that after steam-thermal processing and fine-dispersed comminution of carotene-containing vegetables at preparation of puree takes place the significant increase of extraction of L-ascorbic acid and $\beta$-carotene that is for pumpkin 2 and 3 times more and for carrot 1,7 and 2,5 times more, respectively. The results of researches demonstrated the high effectiveness of the use of new generation of equipment for steam-thermal processing and fine-disperse comminution of carotene-containing vegetables that allowed get the half-finished products and ready products in nanosized form with unique BAS content characteristics that were earlier impossible to be gotten using traditional methods of the vegetable raw material processing and existing equipment $[9,10]$. 
Table 1

Comparative characteristic of carotene of other BAS content in fresh, steam-thermally processed carotenecontaining vegetables, fine-dispersed steam-thermally processed puree and nanostructured cryopuree of them $(\geq 3)$

\begin{tabular}{|c|c|c|c|c|}
\hline \multirow[b]{2}{*}{ Product } & \multicolumn{4}{|c|}{ Mass fraction (mg in $\mathbf{1 0 0} \mathrm{g}$ ) } \\
\hline & $\beta$-carotene & L-ascorbic acid & $\begin{array}{l}\text { Phenol compounds } \\
\text { (by chlorogenic acid) }\end{array}$ & $\begin{array}{l}\text { Flavonol glycosides } \\
\text { (by rutin) }\end{array}$ \\
\hline Fresh carrot & $9,5 \pm 0,3$ & $8,2 \pm 0,2$ & $146 \pm 1,5$ & $50,2 \pm 1,8$ \\
\hline $\begin{array}{l}\text { Carrot steam-thermally processed in } \\
\text { combi-steamer }\end{array}$ & $19,4 \pm 1,8$ & $7,0 \pm 0,3$ & $120,4 \pm 1,4$ & $40,2 \pm 0,9$ \\
\hline $\begin{array}{l}\text { Fine-dispersed steam-thermally } \\
\text { processed carrot puree }\end{array}$ & $24,6 \pm 2,0$ & $15,2 \pm 0,9$ & $200,6 \pm 3,2$ & $85,4 \pm 2,4$ \\
\hline Nanostructured carrot cryopuree & $28,8 \pm 2,5$ & $29,7 \pm 1,5$ & $262,6 \pm 2,8$ & $105,8 \pm 2,8$ \\
\hline Fresh pumpkin & $8,5 \pm 0,3$ & $9,8 \pm 0,2$ & $128,4 \pm 1,8$ & $45,4 \pm 1,2$ \\
\hline $\begin{array}{l}\text { Pumpkin steam-thermally processed } \\
\text { in combi-steamer }\end{array}$ & $20,0 \pm 3,4$ & $8,2 \pm 0,2$ & $95,8 \pm 2,0$ & $39,2 \pm 0,5$ \\
\hline $\begin{array}{l}\text { Fine-dispersed steam-thermally } \\
\text { processed pumpkin puree }\end{array}$ & $26,5 \pm 4,2$ & $16,5 \pm 1,8$ & $210,6 \pm 3,5$ & $78,8 \pm 1,6$ \\
\hline Nanostructired pumpkin cryopuree & $32,2 \pm 2,6$ & $19,7 \pm 1,0$ & $210,6 \pm 2,8$ & $98,6 \pm 1,8$ \\
\hline
\end{tabular}

\section{Conclusions}

It was established, that complex use of the new equipment at steam-thermal processing of vegetable raw material in combi-steamer with fine-dispersed comminution gives a possibility to get puree, which quality is approximated to the one of puree, received using cryogenic processing of product (especially, by the content of $\beta$-carotene and other BAS).

The probation in production conditions of ME "CCF", SPF "KPC", "CRYOS PLUS" (Kharkov, Ukraine) and production of experimental samples of nanoproducts of carotene-containing vegetables prove the expediency of using the new method of deep processing at getting nanoproducts using the new generation of equipment at enterprises of restaurant business and trade. Thus, the aforesaid method of the deep processing of vegetable raw material allows reveal more fully the biological potential of carotene-containing vegetables that can be useful not only in food production but also at getting the natural carotenoid pharmpreparations and additives for immunoprophylaxis of population and so on.

Among the aforesaid methods the most laborious and expensive are traditional methods of the vegetable raw material processing (blanching, boiling, frying and other). It is known, that at their use at the vegetable raw material processing take place the significant wastes $(15 \ldots 30 \%)$ and losses of biological potential of vegetable raw material, not used by people. At that almost half of vegetables harvest is lost at its processing and production of different foodstuff.

The new method of deep processing of carotene-containing vegetables is principally new (unique, cheaper, less laborious), it not only preserves all valuable biologically active and food substances but also allows reveal the biological potential more fully, extract its hidden BAS, associated with biopolymers, into free soluble form. At the same time this method gives a possibility to transform the part of difficultly soluble biopolymers in soluble form - nanoform that is better assimilated by human organism $(2,5 \ldots 3$ times better) $[1,2,4]$. 


\section{References}

[1] FAO/WHO/UNU. Global'naja strategija po pitaniju, fizicheskoj aktivnosti i zdorov'ju (2004). RezoljucijaWHA.55.23 prinjata sessiej Vsemirnoj assamblei zdravoohranenija (VAZ), World Health Organization, Zheneva.

[2] FAO/WHO/UNU. Dietary protein quality evalution in human nutrition (2013). Report of an FAO Expert Consultation. Food and agriculture organization of the united nations Rome, 92-57.

[3] Dherani, M., Murthy, G. V. S., Gupta, S. K., Young, I. S., Maraini, G., Camparini, M., Fletcher, A. E. (2008). Blood Levels of Vitamin C, Carotenoids and Retinol Are Inversely Associated with Cataract in a North Indian Population. Invest. Ophthalmol. Vis. Sci., 49(8), 3328-3335. doi:10.1167/ iovs.07-1202

[4] Pogarskaja, V. V., Pavljuk, R. Ju., Cherevko, A. I., Pavljuk, V. A., Maksimova, N. F. (2013). Aktivacija gidrofil'nyh svojstv karotinoidov rastitel'nogo syr'ja. Kharkov: Finart, 345.

[5] Goñi, I., Serrano, J., \& Saura-Calixto, F. (2006). Bioaccessibility of $\beta$-Carotene, Lutein, and Lycopene from Fruits and Vegetables. Journal of Agricultural and Food Chemistry, 54(15), 5382-5387. doi:10.1021/jf0609835

[6] Rakhimberdieva, M. G., Stadnichuk, I. N., Elanskaya, I. V., Karapetyan, N. V. (2004). Carotenoid-induced quenching of the phycobilisome fluorescence in photosystem II-deficient mutant of Synechocystis sp. FEBS Letters, 574(1-3), 85-88. doi:10.1016/j.febslet.2004.07.087

[7] Oberbajl' K. (1998). Vitaminy celiteli. Sputniki nashogo zdorov'ja. Moscow: Paradoks, 424.

[8] Kirik, I. M. (2009). Parokonvekcionnyj apparat dlja ob'ektov obshhestvennogo pitanija. Innovacionnye tehnologii v pishhevoj promyshlennosti, 394-401.

[9] Pavljuk, R. Ju., Pogars'kaja, V. V., Pavljuk, V. A., Radchenko, L. A. At al. (2015). Krio- i mehanohimija v pishhevyh. Kharkiv:Fakt, 255.

[10] Makaseeva, O. N., Tkachenko, L. M. (2001). Fermenty. Ch. 2. Vitaminy i fermenty. Opredelenie aktivnosti o-difenoloksidazy (polifenoloksidazy) i peroksidazy po Mihlinu i Bronevickoj. Mogilev: Mogilevskij gosudarstvennyj tehnologicheskij institut, 25-27. 